\title{
THE CHARACTERISTICS OF REED LIGHTWEIGHT CLAY BRICKS AFTER DRYING PROCESS
}

\author{
GHAZWAN ABdulsamad Salman \\ Ministry of Higher Education and Scientific Research, \\ Contract Department, Baghdad, Iraq \\ *Corresponding author:ghazwan_salman@yahoo.com
}

(Received: $16^{\text {th }}$ November 2019; Accepted: $11^{\text {th }}$ February 2020; Published on-line: $4^{\text {th }}$ July 2020)

\begin{abstract}
The drying procedure is one of the basic stages in the brick making process, particularly when utilizing the extrusion framing technique. This stage decides the quality and amount of the brick samples. One of the characteristic waste vegetable materials is reed, whish is found in huge amounts in Iraq and numerous other nations. Five weight proportions of reed crumbs $(5,10,15,20$ and $25 \%)$ were utilized to produce lightweight clay bricks. Lab samples were shaped with dimensions of $(25 \times 38 \times 76 \mathrm{~mm})$ using the vacuum extraction method. Brick properties were tested after drying to determine the values of longitudinal drying shrinkage, bulk density, and compression strength. In order to check the property of lightweight clay brick samples, the samples were burned in the furnace at a temperature of $1000^{\circ} \mathrm{C}$ with a burning rate of $2^{\circ} \mathrm{C}$ per minute. The significance of this research is to know the optimal proportions of the reed crumbs that prompts exact control of the drying procedure. This fine control brings about samples of lightweight bricks of the required dimensions and without cracks that influence their properties after drying and become more visible after burning. This knowledge will prompt the decrease of waste in raw materials and energy utilized in the manufacturing of a particular amount of lightweight bricks and, along these lines, reduce the expense of production.
\end{abstract}

ABSTRAK: Prosedur pengeringan merupakan salah satu peringkat asas dalam proses membuat bata, terutamanya apabila menggunakan teknik pembingkaian penyemperitan. Peringkat ini memutuskan kualiti dan jumlah sampel bata. Salah satu daripada bahanbahan sayur-sayuran sisa buatan adalah buluh, ia didapati dalam jumlah besar di Iraq dan banyak negara yang berbeza. Sebanyak 5 buah berat serbuk reed $(5,10,15,20$ dan 25\%) digunakan untuk menghasilkan bata tanah liat yang ringan. Model makmal dibentuk dengan dimensi $(25 \times 38 \times 76 \mathrm{~mm})$ dengan menggunakan kaedah pengekstrakan vakum. Ciri-ciri bata telah diuji selepas pengeringan untuk menentukan nilai-nilai kepekatan pengeringan longitudinal, ketumpatan pukal dan kekuatan mampatan. Untuk memeriksa sampel tanah liat ringan tanahpropertyof, model-model tersebut dibakar dalam relau pada suhu $1000^{\circ} \mathrm{C}$ dengan kadar pembakaran $2^{\circ} \mathrm{C}$ seminit. Kepentingan kajian ini adalah untuk mengetahui perkadaran optimum serbuk reed yang menimbulkan kawalan tepat terhadap prosedur pengeringan. Kawalan halus ini membawa model-model bata yang ringan dari dimensi yang diperlukan dan tanpa retak yang mempengaruhi sifatnya selepas pengeringan dan menjadi lebih terlihat selepas terbakar. Pengetahuan ini akan mendorong penurunan sisa bahan mentah dan tenaga yang digunakan dalam pembuatan sejumlah bata ringan dan di sepanjang garisan ini mengurangkan perbelanjaan pengeluaran.

KEYWORDS:drying process; optimal proportions; vacuum extraction method; reed; lightweight clay bricks 


\section{INTRODUCTION}

The drying procedure is a means of preparing thermally-shaped samples for a specific time frame at a temperature of $110^{\circ} \mathrm{C}$ with the goal that the humidity does not surpass $(25 \%)$ of the initial moistness. This procedure builds the mechanical strength of the samples, which facilitates the process of transfer and placing into the furnaces. The drying procedure is completed in stages where in the primary stage free water among the particles of the clays is lost, causing a convergence of particles with each other leading to the occurrence of dry shrinkage. The shrinkage in the body is equivalent to the measure of vanished water. In the following stage, the thin water surrounding the clay particles vanishes, causing more combinations of the particles and some additional shrinkage. In the last stage, the water in the pores is lost and the water travels through the pores to the particle surface to replace the vanished water from the surface. This stage is described by no shrinkage and the air in the long run replaces the water in the capillary pores, making the dried mass permeable. The drying stages cannot be set and isolated from one another obviously on the grounds that they are overlapping.

Numerous scientists considered the effect of adding agricultural waste to soil in order to create lightweight bricks. One of the most well-known agricultural wastes is rice husk. It has been found that, the perfect proportion of the rice husk ranges from $10-20 \%$ by weight. Adding rice husk to the clay is restricted because it reduces the compression strength of the brick as the rice husk content increases [1,2].

Demir $[3,4,5]$ discovered that the compression strength of the dried brick samples containing sawdust, tobacco, and grass remained unequivocally increased in spite of the increased drying shrinkage of the clay body and these results led to a reduced use of the scraps because of handling issues of unburned blocks.

Similar conclusions were reached by Samia et al. [6], they found that the drying shrinkage and the compression strength before firing were also increased after raising the content of two types of organic waste, namely olive stones and hay, at $1-10 \%$ replacement-to-clay in order to manufacture clay bricks. This behaviour was due to the binding effect of the agricultural waste in the block's structure before burning and that increase was found useful in reducing cracks while transporting bricks to kilns and in maintaining brick dimensions.

Ahmad et al. [7] produced clay samples within the limits allowed for most of the recommended standards by including $5-15 \%$ by weight of coal and wheat peel additives to the clay, moreover the drying shrinkage was found to be lower than $8 \%$ within the limits and decreased with the increase of percentage of additives.

In addition, porosity of the sample can be constrained by the proportion of sawdust mixture and for structural purposes where compression strength is significant, the level of sawdust ought not surpass 10 to 15 percent by weight of the insulating fired bricks [8].

The use of reed morsels for manufacturing of lightweight clay bricks has been exploited in Iraq by the addition of $5-25 \%$ by weight of reed morsels to the clay and the mixes burned at different temperatures of 800,900 and $1000^{\circ} \mathrm{C}$, respectively. The results showed the possibility of manufacturing lightweight clay bricks with comparatively good properties such as bulk density and compression strength in the brick samples containing $5 \%$ by weight of reed crumbs. On the other hand, the results of the studies indicated a decrease in thermal conductivity and longitudinal shrinkage. Moreover, the produced bricks can be made in the same factories that manufacture the ordinary brick clay and in the same step of producing ordinary clay bricks $[9,10]$. 
The purpose of this research was to determine the effects of the addition of reed crumbs in the brick mixture on the drying technique. The bulk density, drying shrinkage and compression strength properties were examined.

\section{MATERIALS}

Physical, chemical and metallic tests were conducted to evaluate the raw materials used in the production of this brick.

\subsection{Soil}

Soil $(100 \mathrm{~kg})$ from two unique quarries was fetched from Al-Nahrawan quarry in the Baghdad zone. The soil was moist and contained masses with a maximum diameter of 5 $\mathrm{cm}$. The soil was cleaned by removing foreign and organic materials from it and then dried in large containers outside the laboratory as a result of exposure to sunlight. After that, the masses of soil were transferred to the oven for drying at a temperature of $110^{\circ} \mathrm{C}$ for 48 hours and pounded with an iron ball plant to be passed through sifter No. 22 (710) micron. Chemical and physical analyses were carried out on the soil sample. The chemical investigation of the clay was done by X-ray fluorescence. Table 1 and 2 show the chemical and physical characteristics of the clay utilized in this research. To decide the grain size distribution of soil utilized, wet sieving and hydrometer technique were utilized based on ASTM D422[13] and ASTM D2487[14]. Table 3demonstrates the grain size distribution of the clay utilized.

Table 1: chemical compounds of the soil utilized

\begin{tabular}{ccc}
\hline Chemical compound & $\begin{array}{c}\text { Content in soil } \\
(\%)\end{array}$ & $\begin{array}{c}\text { Standard requirement [11,12] } \\
\text { (\%) }\end{array}$ \\
\hline $\mathrm{SiO}_{2}$ & 40.80 & $50-60$ \\
$\mathrm{CaO}$ & 16.04 & $5-10$ \\
$\mathrm{Al}_{2} \mathrm{O}_{3}$ & 10.49 & $20-30$ \\
$\mathrm{Fe}_{2} \mathrm{O}_{3}$ & 4.90 & $5-7$ \\
$\mathrm{MgO}$ & 2.42 & 1 \\
$\mathrm{~K}_{2} \mathrm{O}$ & 1.3 & $2-2.76$ \\
$\mathrm{Na}_{2} \mathrm{O}$ & 1.08 & 0.1 \\
$\mathrm{SO}_{3}$ & 2.0 & - \\
$\mathrm{T} . \mathrm{S} . \mathrm{S}$ & 2.28 & - \\
L.O.I & 18.6 & $3-4$ \\
\hline
\end{tabular}

Table 2: physical characteristics of the soil utilized

\begin{tabular}{cccc}
\hline Type of Test & Result & Test Specification & Specification Limit \\
\hline $\begin{array}{c}\text { Moisture Content } \\
\text { \% Atterberg }\end{array}$ & & ASTM D 4318 [12] & \\
Liquid Limit & 32 & & Not more than 55 \\
Plastic Limit & 21.3 & & Not more than 55 \\
Plastic Index & 11.3 & & Not more than 30 \\
\hline
\end{tabular}


Table 3: The grain size distribution of the soil utilized

\begin{tabular}{ccc}
\hline Grain size of soil (\%) & Results (\%) & Typical Range (\%) [13,14] \\
\hline sand & 21 & $20-45$ \\
silt & 45 & $25-45$ \\
clay & 34 & $20-35$ \\
\hline
\end{tabular}

\subsection{Reeds}

The reeds were transported from the banks of a stream in Baghdad as shown in Fig. 1. The reed was cut with a target length of approximately $4 \mathrm{~cm}$. The principal attributes of the reeds utilized appear in Table 4. A manual system was utilized to produce reed crumbs with a little mallet and an electric saw. The reeds were shredded utilizing an electric saw as can be seen in Fig. 2, at that point they were dried in a stove at a temperature of $110^{\circ} \mathrm{C}$ for 48 hours. After the reeds were granulated, the dried reeds were changed over to crumbs using a little mallet and went through strainer 52, size 300 to be prepared for use as an added substance to deliver lightweight blocks, as seen in Fig. 3.

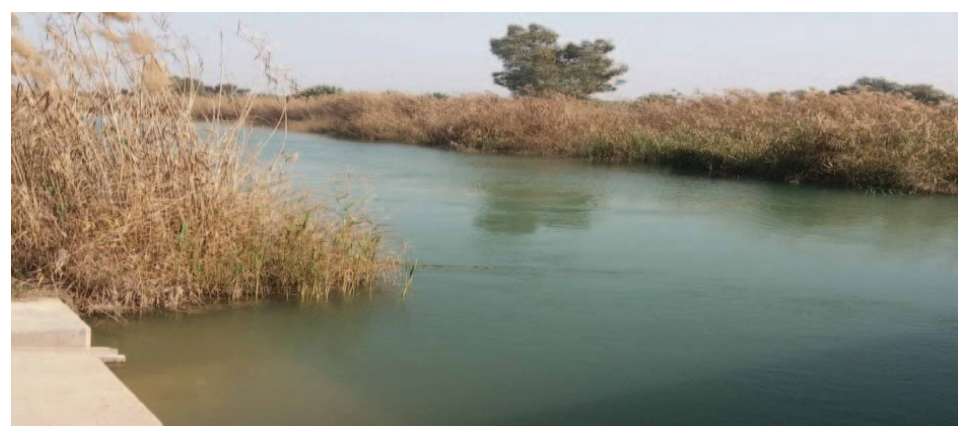

Fig. 1: The reed plants from the banks of the stream.

Table 4: properties of the reeds [15]

\begin{tabular}{ccc}
\hline Characterization & Shortened form & Value \\
\hline Specific gravity & $\mathrm{S} . \mathrm{G}$ & 2.44 \\
Silica (\%) & $\mathrm{SiO}_{2}$ & 65.2 \\
Sulfur trioxide (\%) & $\mathrm{SO}_{3}{ }^{* * *}$ & 1.52 \\
Calcium (\%) & $\mathrm{CaO}$ & 6.4 \\
Alumina (\%) & $\mathrm{Al}_{2} \mathrm{O}_{3}$ & 12.3 \\
Iron (\%) & $\mathrm{Fe}_{2} \mathrm{O}_{3}$ & 2.6 \\
Potassium (\%) & $\mathrm{K}_{2} \mathrm{O}^{* *}$ & 2.5 \\
Chloride (\%) & $\mathrm{CI}$ & N.R \\
Sodium (\%) & $\mathrm{Na}_{2} \mathrm{O}$ & $\mathrm{N} . \mathrm{R}$ \\
Phosphorus (\%) & $\mathrm{P}_{2} \mathrm{O}_{5}$ & 0.03 \\
Magnesium (\%) & $\mathrm{MgO}$ & $\mathrm{N} . \mathrm{R}$ \\
Titanium (\%) & $\mathrm{TiO}_{2}$ & 0.19 \\
Manganese (\%) & $\mathrm{MnO}_{\text {MnO }}$ & 0.08 \\
Moisture Content (\%) & w & 0 \\
Loss on Ignition (\%) & $\mathrm{L} . \mathrm{O} . \mathrm{I}$ & 1.47 \\
\hline
\end{tabular}

*Chemical compound values are determined utilizing EDX-7000 instrument.

$* * \mathrm{~K}_{2} \mathrm{O}$ value is determined utilizing XRD-6000 instrument.

*** $\mathrm{SO}_{3}$ value is determined utilizing MXF-2400 instrument. 


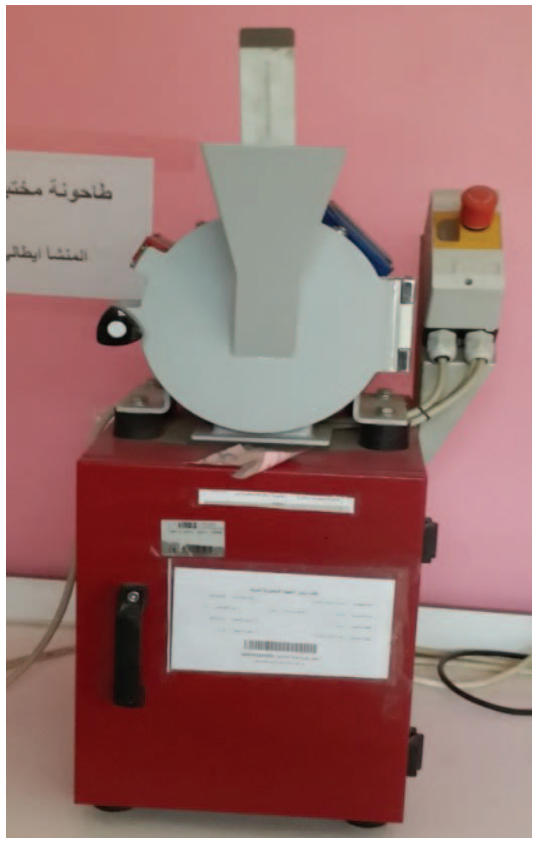

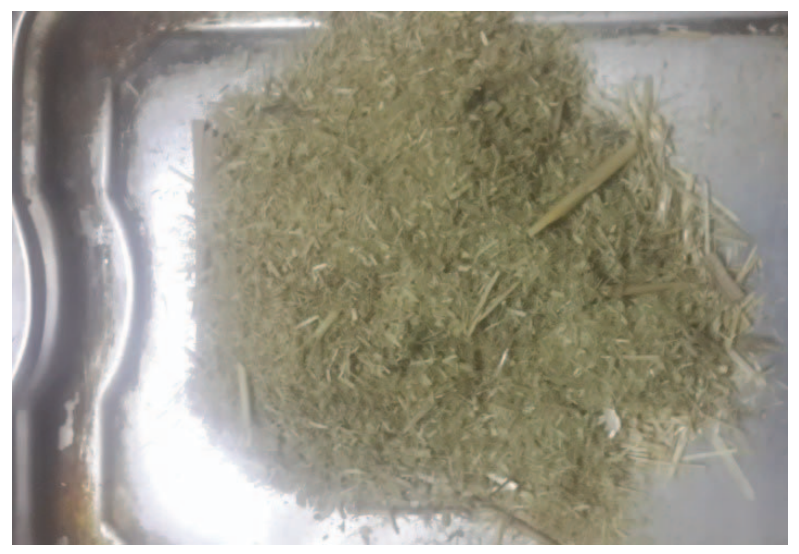

Fig. 3: The reed crumbs produced in this study.

Fig. 2: Electrical saw

Table 5: Plasticity coefficients of soil with and without different percentages of reeds crumbs.

\begin{tabular}{ccc}
\hline Mix symbol & Raw materials & Plasticity index (\%) \\
\hline S & Soil (reference) & 31 \\
S1 & Soil + 5\% RC & 34 \\
S2 & Soil + 10\% RC & 38 \\
S3 & Soil +15\% RC & 44 \\
S4 & Soil + 20\% RC & 49 \\
S5 & Soil + 25\% RC & 52 \\
\hline
\end{tabular}

*Where $\mathrm{RC}=$ reed crumbs

\section{MIX PROPORTIONS AND MIXING PROCESS}

The production of lightweight clay block mixtures was done by adding $(5,15$, and $25 \%$ ) by weight of the reed crumbs to the clay. The Pefferkorn method was used for deciding the measure of water required for changing the plasticity index with the different percentage of the reed additions. Table 5 shows the plasticity coefficients for mixes of soil with and without various rates of the additional reeds crumbs. The blending procedure was done in a bigpan and the mixture bowl was cleaned before each blending procedure. To set up the reference blend, the clay was soaked with the fundamental water (as indicated by the plasticity coefficient) and the blending procedure was done in the big pan for 15 minutes so as to acquire a homogeneous blend. Concerning blends containing reed crumbs, the specified quantities of soil and reed morsels were blended into the skillet for 10 minutes without adding any water in order to get a homogeneous blend. Then the water was added to the dry blend and blended for another 15 minutes. After the blending procedure is finished, the blend is set in a closed loop container for 24 hours to guarantee the homogeneity of water and soil in the blend. 


\section{SAMPLE PREPARATION, DRYING AND FIRING}

The soil blocks were produced in the lab by an extruded expulsion of air technique, using a vacuum extruder (Fig. 4). Specimens of $75 \mathrm{~mm}$ length, $38 \mathrm{~mm}$ width, and thickness of $25 \mathrm{~mm}$ height measurements were made. The drying method was started by leaving the framed soil samples in the lab for 7 days and then drying them in a stove at a temperature of $110 \pm 5^{\circ} \mathrm{C}$ for 48 hours. Later the block samples were taken away from the stove and left to cool at a lab temperature of $23 \pm 2^{\circ} \mathrm{C}$ for 48 hours. The dried specimens were transferred to an electric kiln to start the firing procedure where the warming rate and the soaking time were constant.

The dried blocks were sorted inside the kiln, (Fig. 5) in an effort to guarantee that the warmth reached all surfaces of the samples uniformly. The dried clay blocks were burned at a $1000^{\circ} \mathrm{C}$ degree of firing by electrical kiln (Fig. 6). The dried blocks of every blend were burned independently using a similar firing program and at the time of drenching for two hours until arriving at the planned firing temperature $1000^{\circ} \mathrm{C}$. The firing rate was $2^{\circ} \mathrm{C}$ per minute, to guarantee adequate time for firing of every natural material with the complete arrival of carbon dioxide. After the firing procedure was finished, the kiln was turned off and the block samples were left inside until the temperature decreased to the temperature of the lab. In order to ensure a lightweight block, bulk density and compression strength tests were performed.

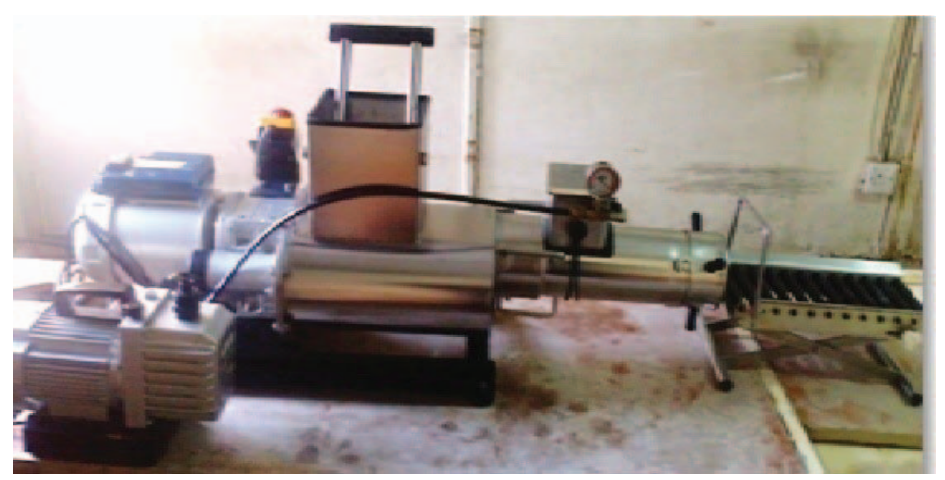

Fig. 4: Clay extrusion device.

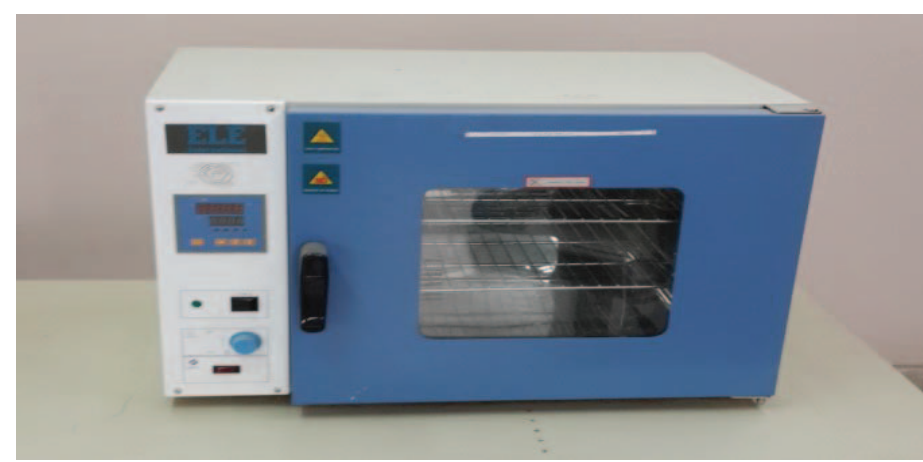

Fig. 5:.Curing and drying furnace. 


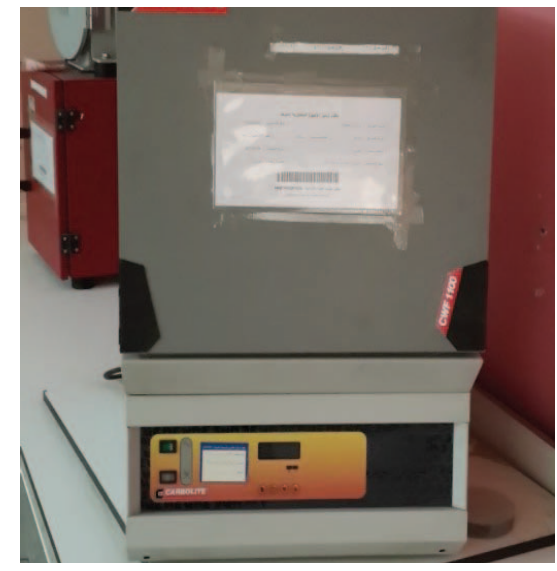

Fig. 6:.Burning furnace.

\section{TEST PROCEDURE}

\subsection{Longitudinal Shrinkage Test}

One of the significant properties after the drying process of reed lightweight clay bricks is the shrinkage of the clay mass, which mainly affects the accuracy of the final brick dimensions and the bulk density. The longitudinal shrinkage test was carried out according to specification [16] after drying the brick samples at a temperature of $110^{\circ} \mathrm{C}$ for 48 hours and then cooling to the laboratory temperature of $23 \pm 2^{\circ} \mathrm{C}$. The length of the sample was measured before and after drying from two different sides and the average length was recorded. The length of brick blocks was measured after and before the drying process to determine the longitudinal shrinkage proportion. The following equation was used to calculate the longitudinal shrinkage:

$$
\text { (L.S)\% }=\left(\frac{H d-H r}{H d}\right) \times 100
$$

where: (L. S) = Longitudinal shrinkage, $\mathrm{H} d=$ Sample length before drying process $(\mathrm{mm})$ andHr=Sample length after drying process $(\mathrm{mm})$. An average of 10 specimens was used.

\subsection{Bulk Density Test}

The bulk density of the samples was determined based on the specification [14] and after drying process by weighing them with a high sensitivity electric balance and accuracy up to $\pm 0.01 \mathrm{~g}$. Dimension measurements were performed on two sides with a Vernier caliper and the rate was recorded. An average of 10 specimens was used. The bulk density of the dried lab samples was estimated using equation (2):

$$
B \cdot D=\frac{W}{V}
$$

where: $B . D=$ Bulk density $\left(\mathrm{g} / \mathrm{cm}^{3}\right), \mathrm{W}=$ weight of samples after drying $(\mathrm{g})$ and $V=$ Volume of samples after drying $\left(\mathrm{cm}^{3}\right)$.

The same equation was used to calculate the bulk density after the burning process. The bulk density of the firing block samples was determined as per ASTM C373 [17].

\subsection{Compression Strength Tests}

The values of the compression strength tests after drying are influenced by cracks and defects that show up in the sample bricks and are considered to be a primary measure of the final compression strength of these samples after burning. The increase in the compression strength of the dried samples is an indication of the lack of cracks and other 
defects in the brick samples, which helps not to damage them during the loading and transporting process before burning. This test began after the samples were dried at $110^{\circ} \mathrm{C}$ and cooled to the laboratory temperature. The test was carried out by covering the top and bottom surfaces of the sample with two pieces of $3 \mathrm{~mm}$-thick plywood to ensure uniform distribution of the load on the loading surface as seen in Fig. 7 and Fig. 8. A load of 15 $\mathrm{N} / \mathrm{mm}^{2}$ per minute was applied until failure occurred. Compression strength for each sample was calculated from the following relationship:

$$
C=\frac{P}{A}
$$

where: $C=$ Compression strength $\left(\mathrm{N} / \mathrm{mm}^{2}\right), P=$ The applied loading when the sample fails and $A=$ The area of the sample which exposed to the applied load.

An average of 10 specimens was used. The compression strength after firing process was determined according to ASTM standard ASTM C373-88[17] using Eq. 3.

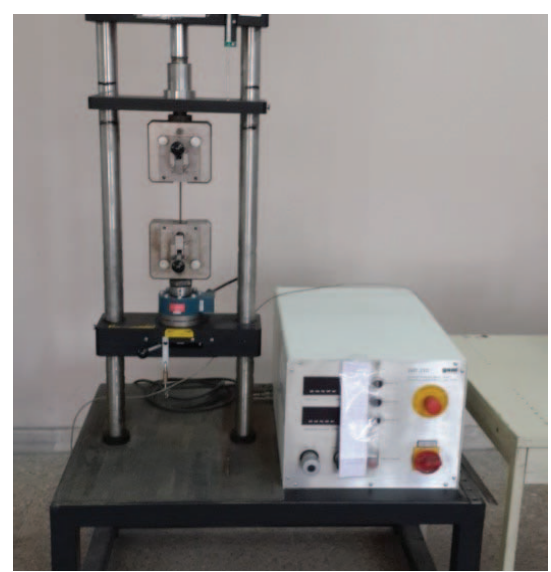

Fig. 7: Compressive strength test machine.

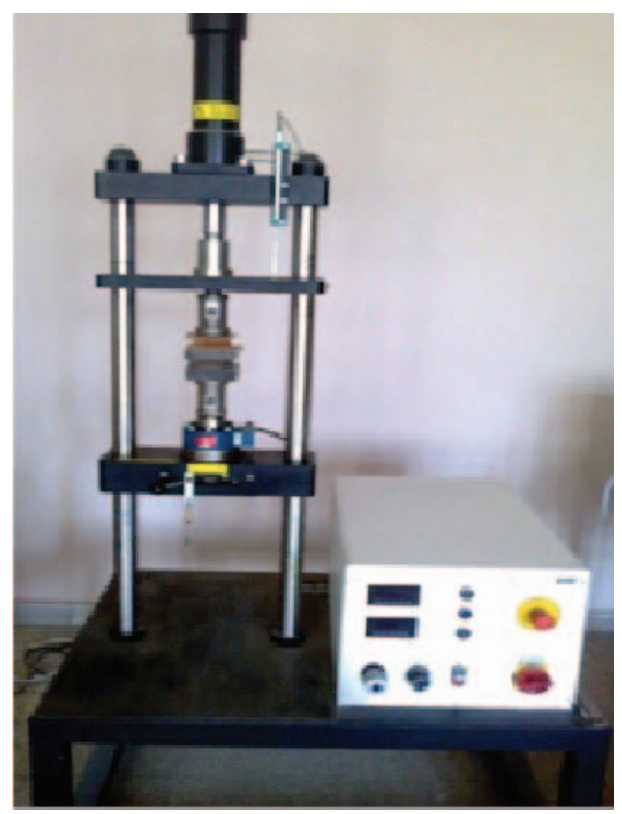

Fig. 8: Sample under compressive strength test. 


\section{RESULTS AND DISCUSSION}

From these experiments, it was observed that the amount of moisture increased for the formation of brick samples with the addition of reed crumbs. This behaviour was due to the addition of reed crumbs which resulted in more difficult extrusion. This is due to the fibrous nature of the reed crumbs and their internal water channels that lead to increased water absorption which is the main reason for the increasing demand for water. Some difficulties occurred during the mixing and extrusion process when the percentage of the reed crumbs reached $20 \%-25 \%$ due to the fibrous nature of the reed. No defects were observed after the drying process of the samples except for the samples with the addition of 20 and $25 \%$ of reed crumbs, where small cracks occurred and increased with the percentage of reed crumbs added during the drying process, resulting in failure during firing. Splits, swelling, and other perceptible deformities are seen after the burning procedure for the samples with 20 and $25 \%$ of reed crumbs. After combustion, an increase in weight loss when ignition is observed in block samples containing high levels of reed crumbs compared to samples with little or no additive ratio. Increased demand for energy was also noted during the firing process due to the high amount of water needed to form the brick samples. No black cores were seen in broken samples after the compression strength test. Lightweight clay bricks were created by merging no more than $5 \%$ (by weight) of reed crumbs into soil which met the compression strength prerequisites of blocks utilized for partitions, as indicated in ASTM Standard C62 [18].

\subsection{Longitudinal Shrinkage}

The drying shrinkage property is influenced by the method used to form the bricks. The extrusion method used in the formation of bricks needs a higher water content than the critical water content and an increase in the formation water content leads to increased drying shrinkage causing contraction in the body of the brick [19]. The results of the longitudinal shrinkage after drying process were shown in Fig. 9. A high increase in the drying shrinkage values was observed in the samples compared to the control (clay only). The percentage of increase for longitudinal drying shrinkage were 7.3, 17.08, 34.15, 43.90 , and $68.29 \%$ for S1, S2, S3, S4, and S5 samples respectively compared to reference mix $\mathrm{S}$. This linear increase in longitudinal drying shrinkage is attributed to the increase in the percentage of reed crumbs that led to an increase in the formation water content and plasticity index due to the fibrous nature of reeds that absorb water, which results in higher shrinkage values after drying as plotted in Fig. 9. However, despite of increment in the plasticity index, the longitudinal drying shrinkage does not increase to the same degree, as we can see in Fig. 10. This condition is because of the hollow and sorbent nature of the reed crumbs which somewhat balances out the drying conduct of the clay body notwithstanding the increment in water demand with the increment of reed crumbs. In general, the longitudinal drying shrinkage values of the clay mixtures containing reed crumbs were higher than the longitudinal drying shrinkage value of the reference mixture samples. This conclusion was reached by a group of researchers who used different types of agricultural waste in a number of lightweight brick industry research $[3,4,5,6]$. This behaviour continues after burning the brick samples as can be seen of the longitudinal shrinkage results in Fig. 10. The percentage of increase in longitudinal shrinkage values of the fired samples was $11.98,21.87,32.30,41.15$ and $52.08 \%$ for the mixes S1, S2, S3, S4, and S5 respectively compared to the reference mix S. Accordingly, there is a direct increment in the drying and complete longitudinal shrinkage as the quantity of reed crumbs in the blend increases. Brick samples containing $20-25 \%$ of reed crumbs were found to be unsuitable due to high shrinkage after drying which caused large cracks after burning. 


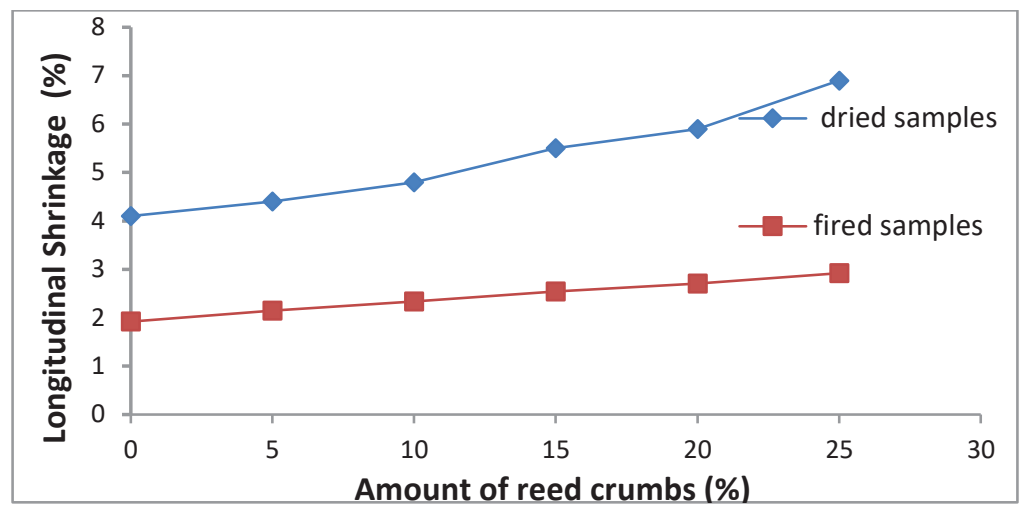

Fig. 9: Effects of \% reed addition on longitudinal shrinkage of dried and fired clay brick samples

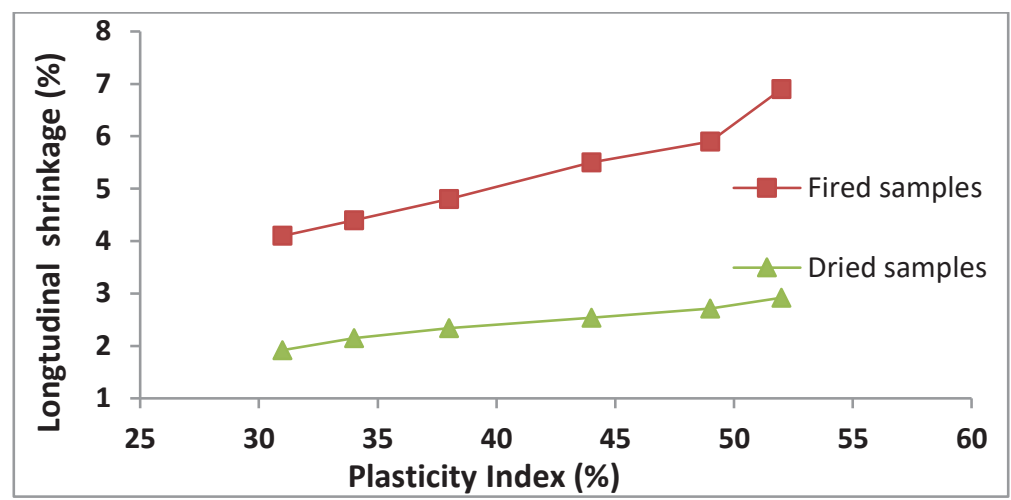

Fig. 10: The relationship between longitudinal shrinkage and the plasticity index of dried and fired brick samples.

\subsection{Bulk Density}

The results of the bulk density tests after the drying are shown in Fig. 11. These results showed that the values of bulk density after drying gradually decreased for mixing samples S1, S2, S3, S4 and S5 compared to the reference mixture samples (S). The percentage of decrease was 8.13, 16.06, 21.83, 27.68, and 30.24\% for S1, S2, S3, S4, and $\mathrm{S} 5$ respectively compared to reference sample S. This indicates that bulk density after drying of samples containing reed crumbs is lower than that of samples manufactured from brick clay only as shown in Fig. 11.A rise in the quantity of reed crumbs brings about more decreases in bulk density values. This reduction in the bulk density of the samples containing reed crumbs is due to the decrease in the proportion of clay in the blend, which was replaced by reed crumbs with less density than the clay. In addition, the increase in the amount of water to maintain the plasticity required for the mixture with an increase in the proportion of reed crumbs, which subsequently evaporates after the end of the drying process, leads to more decrease in the dry density. Similar findings were reached in several previous studies that used different types of agricultural waste as clay replacement material in brick. According to $[3,4,5,6]$ the addition of different agricultural waste such as Kraft pulp production residues, processed waste tea, sawdust, tobacco, grass, olive stones, and hay to the soil used for the production of clay bricks leads to a reduction in the bulk density of the brick samples. This is due to the partial replacement of high density of soil with a low density additive such as the agricultural waste in addition to the high plasticity coefficients of the mixing samples S1, S2, S3, S4 and S5 with increasing ratios of 
addition, which leads to a decrease in density of the samples. In addition, bulk densities of the samples containing reed crumbs after firing have a lower value compared to the reference samples made from clay only. The bulk density test results of samples containing reed crumbs after firing are plotted in Figure11. The level of reduction was $12.73,23.35,25.90,36.77$ and $41.93 \%$ for S1, S2, S3, S4, and S5 samples individually contrasted with S. Further reed crumbs increase in mixes S1-S5 caused just a slight further decrease. The burning of reed crumbs through the sintering time is the main reason behind this behaviour.

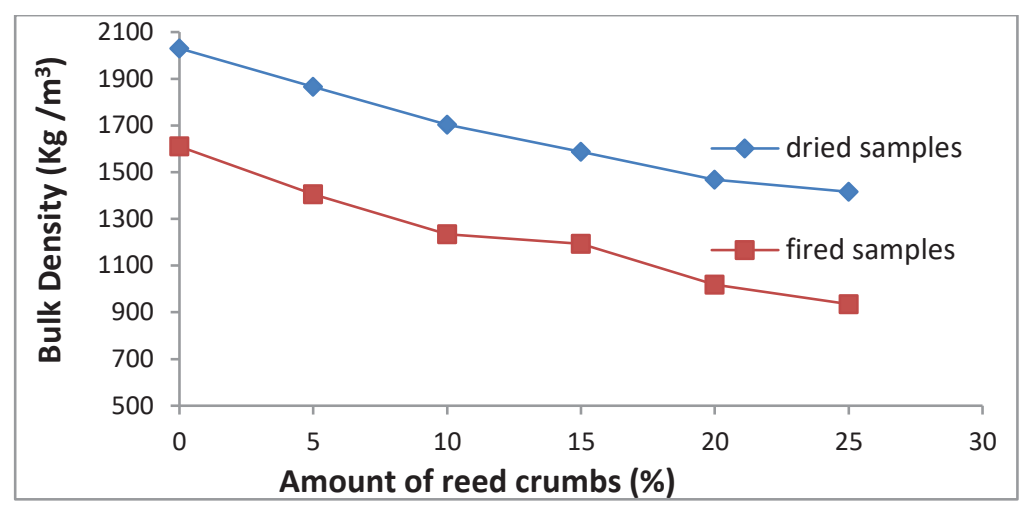

Fig. 11: Effects of amount of reed on bulk density of dried and fired clay brick samples.

\subsection{Compression Strength}

Compression strength after drying is influenced by several factors, the most important factors are the type and percentages of additives. Agricultural waste additives are characterized by their fibrous nature. The compression strength depends on the strength of these fibers. Compression strength increases with the increase of the fiber's strength and decreases with lower strength [5]. Another factor affecting compression strength after drying is formation water content. An increase in formation water content leads to the separation of the clay molecules from each other and the decrease of body strength, in addition to the increase in the proportion of capillary cracks formed due to drying shrinking with the increase of the formation water content which causes the weakening of the body and leads to reduced strength. The results of compression strength tests after drying are shown in Fig. 12. As can be seen in Fig. 11, mixes S1, S2, and S3, which contain 5, 10 and $15 \%$ of reed crumbs, have higher compression strength after drying compared to the reference mixture (S), which is made solely from soil. The level of increment of the blends of S1, S2, and S3 was 29.26,42.89 and 7.95\% contrasted with a reference blend $\mathrm{S}$. This behaviour was due to the fibre strengthening effect of the of reed crumbs with low porosity which increase compression strength of samples S1, S2, and S3. This result is similar to the findings of the group of researchers who pointed to the increase in compression strength with $5-10 \%$ clay replacement with different types of agricultural waste in a number of lightweight clay brick industry research. According to [3-6], the addition of $5-10 \%$ of different agricultural waste such as Kraft pulp production residues, processed waste tea, sawdust, tobacco, grass, olive stones and hay to the soil used for production clay bricks leads to increase in compression strength after drying. As they discovered, this phenomenon is due to the fibre strength of agricultural waste with low porosity that leads to increase the compression strength after drying. This increase in compression strength after drying was discovered to be extremely valuable in avoiding the handling problems of the lightweight clay brick. Subsequently, the increase in reed crumbs to $20 \%$ of weight and then $25 \%$ of weight resulted in reduced compression strength after 
drying of mixtures S4 and S5 respectively compared to the reference mixture S. The level of decrease in compression strength was 28.98 and $48.86 \%$ for blends S4 and S5 in comparison with a reference blend $\mathrm{S}$. This decrease in compression strength after drying is due to the increase in porosity of the brick body to a high degree due to the high content of the formation water which overcomes the strength of the fibrous nature of reed crumbs. As shown in Fig. 12, the compression strength values after burning was decreased with the increase of the addition of reed crumbs to soil. The level of reduction was 19.1, 36.8, 49, 66.56 , and $75.23 \%$ for blends S1, S2, S3, S4, and S5 individually comparing with a reference blend $\mathrm{S}$. The reduction in compression strength after burning with the increase in the rate of addition of reeds crumbs was due to the increase in the amount of carbon dioxide gas caused by the combustion of carbon materials as well as the gaps left by the penetrating gas, which increase the porosity of the body and thus reduce the resistance of the brick body. Replacing part of the soil with reed crumbs also reduces the clay content in the mass, this clay content is responsible for forming the crystalline minerals which increasing the compression strength of the product $[6,9]$.

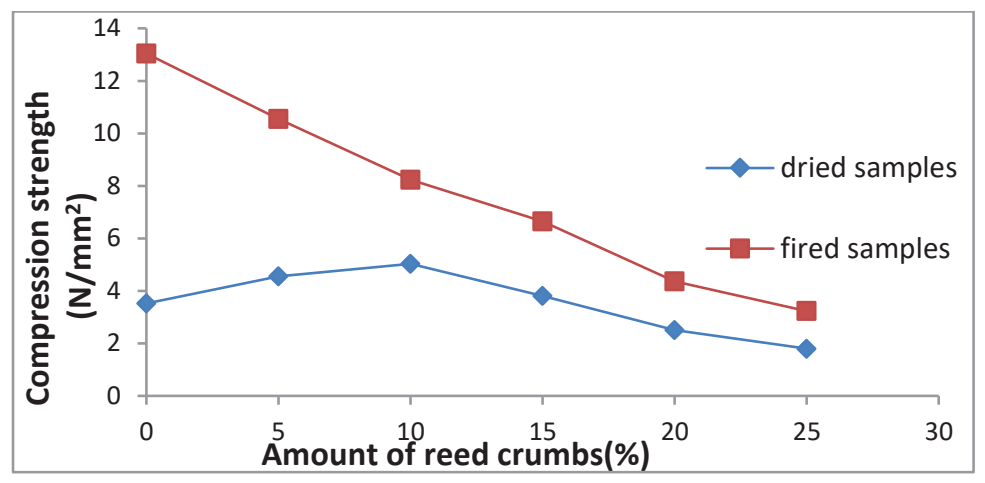

Fig. 12: Effects of \% reed addition on compression strength of dried and fired clay brick samples.

\section{CONCLUSION}

Lightweight clay brick samples were manufactured by incorporating 5-25\% (by weight) of reed crumbs into soil. Lightweight clay bricks samples meeting the requirements for blocks used for partitions, as indicated by ASTM Standard C62 [18], were made by adding 5\% of reed crumbs into soil. The following conclusions were reached based on the results of laboratory tests on the manufactured brick samples:

-The addition of reed crumbs to the mixes of clay bricks caused no difficulties during the blending and extrusion process, but at the same time increased the required water content to keep the plasticity of the reed clay mixture. Hence, this leads to an increase of the water content and plasticity coefficient simultaneously. The increase in plasticity coefficient ranged from 9.7 to $22.58 \%$ when the reed crumbs were added in percentages ranging from 5 to $25 \%$ to the brick mixture. The ability of water channels within cellulose fibres to naturally absorb water is believed to be the main reason for the increased water demand in order to maintain the plasticity.

-A higher increase was found in the longitudinal drying shrinkage of reed-containing specimens than that of the brick clay sample only. The level of increment was discovered to range from 7.3 to $68.29 \%$ when the addition of reed crumbs ranged from 5 to $25 \%$. This action is due to the increase in the water content needed to maintain the plasticity of the mixture when adding reed crumbs. Ratios of addition 
of 20 and $25 \%$ of reed crumbs to brick mixtures was found unsuitable for brick making due to high shrinkage after burning.

- The rate of increase in the longitudinal drying shrinkage is less than the rate of increase in plasticity coefficient when the same percentage of reed crumbs are added to the slurry mixture of the brick samples.

-The bulk density values for dried samples containing reed crumbs were lower than that of clay samples only. The percentage decrease in bulk density values for brick samples with an added 5,10,15, 20 and $25 \%$ of reed crumbs was $8.13,16.06$, 21.83 and $27.68 \%$ respectively compared to samples made from clay only. This behaviour is due to the replacement of part of the high-density clay with lowdensity reed crumbs which increased plasticity coefficient of these mixtures.

- The ratios of adding up to $15 \%$ of reed crumbs were discovered to considerably increase the dry compression strength of the clay samples. The ratio of increase in compression strength values was $29.26,42.89$, and $7.95 \%$ when including 5, 10, and $15 \%$ of the reed crumbs to the clay blends respectively compared with the reference samples produced from the clay only. This behaviour was due to the fibre strength of reed crumbs which increase the dry compression strength; this increase was found very valuable in avoiding handling problems.

-Increasing the additives of reed crumbs more than $15 \%$ causes a reduction in compression strength after drying. The ratio of reduction in compression strength values was 28.98 and $48.86 \%$ when adding 20 and $25 \%$ of the reed crumbs to the clay blends respectively compared with the reference samples produced from the clay only. This reduction in compression strength after drying was found due to the increase of water content and plasticity coefficient in order to keep the plasticity of clay mixture which increased porosity and cracks after drying.

-Generally, the reed crumbs can be used as a type of additive to form pores in the clay body without any detrimental effect on the drying process of lightweight clay bricks. Conversely, the addition of these reed crumbs was found very valuable in preventing handling problems of the lightweight clay bricks due to the increases in the compression strength after drying caused by the strength of the reed fibres.

-The percentage of the scraps resulting from the handling problems of unfired bricks were found to be low when the reed crumbs were added by no more than $10 \%$. A high percentage of the scraps were seen when the addition of reed crumbs was more than $15 \%$. This knowledge is very important in order to maintain the raw materials from loss when using high percentages of reed crumbs.

\section{ACKNOWLEDGEMENT}

The researcher would like to express profound thanks and appreciation to Prof.Dr.Shakir Ahmed Salih for his support and encouragement during the planning of this research.

\section{REFERENCES}

[1] Görhan G, ŞimşekO.(2013)Porous clay bricks manufactured with rice husks. Construction and Building Material,40:390-396.

[2] Carter GW, Cannor AM, Mansell DS. (1982) Properties of bricks incorporating ungrounded rice husks. Build Environmental, 17(4): 285-291. 
[3] Ismail D,SerhatB, Mehmet O .(2004) Utilization of kraft pulp production residues in clay brick production. Building and Environment, 40: 1533-1537.

[4] Demir I. (2005) An investigation on the production of construction brick with processed waste tea. Building and Environment,41:1274-1278.

[5] Demir I. (2007) Effect of organic residues addition on the technological properties of clay bricks. Waste Management,28:622-627.

[6] Arezki S, Chelouah N, TahakourtA.(2015)Study of the influence of agricultural waste on the porosity of clay brick,Available online: http://fstroj.uniza.sk/journal-mi/PDF/2015/03-.pdf .

[7] Safeer A, Yaseen I, RazM.(2017) Effects of coal and wheat husk additives on the physical, thermal and mechanical properties of clay bricks, Boletín De La Sociedad Española De Cerámica Y Vidrio, 56:131-138.

[8] Kumar, A. Mohanta, K. Kumar, D. and Parkash, O. (2012).Properties and industrial applications of rice husk. J. Engineering Technology and Advanced Engineering, 2:5-10.

[9] GhazwanS,Shakir S. (2019) Effect of firing temperatures on physico-mechanical properties of clay bricks containing reeds. International Journal on Advanced Science, Engineering and Information Technology, 9(1):321-238.

[10] GhazwanS,Shakir S. (2018) Effect of burning temperature of clay bricks containing reeds on its longitudinal shrinkage, modulus of rapture and thermal conductivity. International Journal of Civil Engineering and Technology, 9(9):1388-1402.

[11] ASTM D 4327 (2013)Determining chloride and sulfate contents in soils.ASTM International, West Conshohoken, PA, USA.,

[12] ASTM D 4318(2006)Standard test method for liquid limit, plastic limit, and plasticity index of soils. Annual book of ASTM standards.

[13] ASTM D422 (2006)Standard test method for particle size analysis of soils.Annual book of ASTM standards.

[14] ASTM D2487 (2011) Standard practice for classification of soils for engineering purposes (Unified System)". ASTM International, West Conshohocken, PA, USA.

[15] Karim HH, Samuel ZW, Ahmed SF.(2015)Geotechnical properties of soft clay soil stabilized by reed ashes, 2nd International conference on Buildings, Construction and Environmental Engineering.

[16] Beech, DG(1974). Testing methods for brick and tile manufacture, Britain Ceramic Research Association.Publication(84).

[17] ASTM C 373 (2006)Standard test method for water absorption, bulk density, apparent density and apparent specific gravity of fired whitewares products", Annual book of ASTM standards,.

[18] ASTM Standard C 62.(2006) Standard Specification for Building Brick (Solid Masonry Units Made From Clay or Shale)," Annual book of ASTM standards, 2006.

[19] Clews FH. (1969) Heavy Clay Technology, $2^{\text {nd }}$ ed., New York, pp 9-16. 